\title{
Bollworms chew hole in gene-engineered cotton
}

Washington. A large question mark is hanging over the effectiveness and safety of one of the first genetically-engineered crops to be extensively planted, after cotton bollworms were found to have infested thousands of acres planted with the new breed of cotton in Texas.

Two million acres of so-called ' $B t$ cotton' have been planted for the first time this year, after the crop was approved last autumn by the US Environmental Protection Agency (EPA). The crop is named after the soil bacterium Bacillus thuringiensis, genetic characteristics of which are introduced into the cotton to produce a natural insecticide.

Scientists from the chemicals company Monsanto, which has invested millions of dollars to develop the crop, are this week collecting samples of planted seeds and bollworms to investigate the apparent breakdown in the crop's effectiveness.

Shares in Delta and Pine Land, which distributes the crop for Monsanto, were briefly suspended on the New York Stock Exchange on 15 July as news of the problem spread to Wall Street. Trading resumed at $\$ 26$, down from $\$ 33$ before the suspension.

The Union of Concerned Scientists (UCS), which has opposed certain applications of genetic engineering, called on the EPA to suspend registration of the sale of $B t$ cotton. But the EPA is waiting for data from Monsanto's scientists before deciding how to respond. Lynn Goldman, assistant administrator of the EPA, says: "We hope the issue can be resolved within weeks. But if $B t$ cotton doesn't work, it doesn't matter if we give them registration or not - they [Monsanto] aren't going to have a product."

With two million acres planted from Georgia to Texas - out of a total of about 15 million acres under cotton in the United States - Bt cotton is perhaps the most economically significant of all genetically engineered plants introduced in the country.

The genetically engineered cotton generates a natural toxin to kill caterpillars of three pests: cotton bollworm, tobacco budworm and pink bollworm. Critics fear that it may produce a generation of insects with resistance to the natural toxin. These would then attack the crops of organic farmers who rely on spraying with the natural toxins.

To avoid this risk, the EPA only allowed $B t$ cotton to be planted subject to a resistance management plan. This requires that the dose of toxin in the plants is high enough to kill almost all insects exposed to it, so that few survive to breed. Farmers must also keep some non-engineered crops nearby, to retain a population of non-resistant insects. Insects that do survive natural toxin will then interbreed with 'normal' insects, preventing the development of a super-resistant strain.

Margaret Mellon of UCS says: "The cotton's failure to control bollworm indicates that the current management plan will not work for at least one pest. EPA should suspend the registration and bar sales of $B t$ cotton until the company develops a new resistance management plan that will work."

Monsanto says, however, that the plan works differently for different pests. Randy Deaton, the company's manager in charge of $B t$ cotton development, says that the cotton bollworm is unlikely to develop resistance, because it lives on so many plants other than cotton. "The biggest concern for

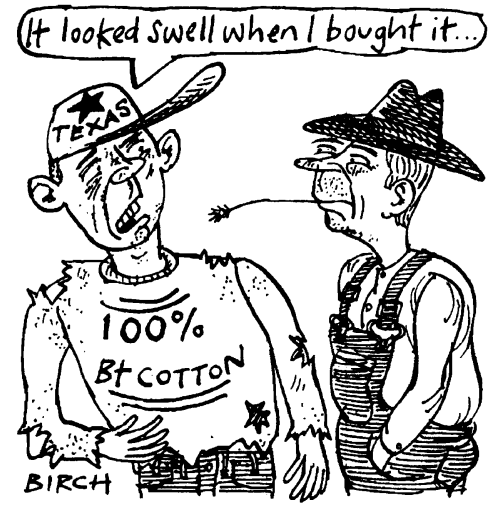

resistance is the tobacco budworm," he says. The budworm is killed by a lower dose of the natural toxin, and there is no evidence that it is surviving in $B t$ cotton.

According to Randy Luttrell of the agriculture school at Mississippi State University, the Mississippi farmers who paid a \$32-per-acre licence fee for the crop did so primarily for protection against tobacco budworm. But some farmers in the state are spraying $B t$ cotton as a precaution, he says.

Deaton says: "Growers have a natural anxiety this time of year. They'd be on edge no matter what." He declined to comment on rumours that insecticide suppliers are spreading stories about $B t$ cotton's failures to discredit the genetically-engineered crop, which would need no spraying if it worked properly.

Goldman says that the EPA will get data this week from Monsanto on whether the surviving bollworms are of a resistant strain. The genetically-engineered plant includes a marker gene to enable scientists to establish if infested plants are $B t$ cotton, or if a mix-up with seeds has contributed to the problem.

Monsanto hopes that the efficacy of its cotton plants has merely been limited by the severe drought in Texas, and that farmers will soon regain confidence in $B t$ cotton. "It has lots of benefits for growers and lots of benefits for the environment," says Deaton.

Colin Macilwain

\section{RIghts issue take-up for British Biotech 'disappointing'}

London. The largest single fundraising attempt by a UK biotechnology company met with mixed reactions last week when only 49 per cent of shareholders in British Biotech took up their rights to buy additional shares.

Small biotechnology companies in the United States and United Kingdom raised almost $£ 2.11$ billion ( $\$ 3.3$ billion) in public offerings in the year to $11 \mathrm{July}$, so the low take-up for the rights issue was a disappointment to British Biotech. But not a disaster, because underwriter Kleinwort Benson is to pay any shortfall in the $£ 143$ million anticipated.

Launched in 1986 and now valued at $£ 1.4$ billion, British Biotech has yet to bring a product to market, but is pinning its hopes on lexipafant, a treatment for pancreatitis, and the anticancer drug marimastat.

When promising results from phase I and II studies on marimastat were presented to the American Society of Clinical Oncology in May, the company's stock rose to $£ 32.65$. The drug appears to be active in patients with advanced pancreatic carcinoma, can be given orally and seems to be tolerated well. But the two-year phase III trials have only just begun. A spokeswoman for British Biotech is confident that "everything remains on track at the company" and there will be no need to generate further capital to bring marimastat to the market.

While the larger biotechnology companies remain fairly secure, new ones springing up in the wake of their success may face a struggle for funds.

Mike Ward, editor of BioBusiness, believes that the experience of British Biotech was not due to any "negative news" about the company, but rather that it comes at a time when too many companies are chasing a finite number of investors. "The well has run dry," he says. He admits that the risk inherent in the biotechnology sector may be best taken, or at least judged, by the larger pharmaceutical companies. Cantab Pharmaceuticals, one of the smaller companies, celebrated a dramatic rise in its share price last week on the announcement of its collaboration with Smith-Kline Beecham to develop a vaccine for genital warts.

There are concerns that relying on large companies to foster drug development means that treatments destined only for a limited market will remain unfunded. In the United States, companies may apply for 'orphan drug' status for such treatments, ensuring a monopoly position for the first seven years of marketing. The European Union is considering similar legislation. Ginny Page 